\title{
the HISTORIAN
}

(C) 2014 Phi Alpha Theta

\section{UNCERTAIN FATES: \\ Allied Soldiers AT The M I R A N A D E E B R O C O N C E N T R A T I O N C A M P} Matilde Eiroa and Concha Pallarés

In the wake of a 2003 international congress on concentration camps and other centers of repression in Franco's Spain, reports describing detainees' survival mechanisms and the actions and procedures carried out in Spanish, French, and German concentration camps, where a significant number of Spanish Republicans lived for months following the Spanish Civil War, have proliferated. Among them stands out the pioneering work of Joan Llarch and that by Adrián Blas, as well as Javier Rodrigo's most recent publications, who analyze the organization, legislation and other aspects. ${ }^{1}$ Also available are studies by British and French historians

Matilde Eiroa is a lecturer in the School of Humanities and Communication at the University Carlos III de Madrid. Her publications include studies about Spanish Civil War and Francoism such as Política internacional y comunicación en España, 1939-1975. Las cumbres de Franco con Jefes de Estado (Madrid: Ministerio de Asuntos Exteriores, 2009) and "Brigadas Internacionales, la solidaridad de la izquierda" in A. Viñas (ed.), En el combate por la Historia. La República, la Guerra Civil, el Franquismo (Barcelona: Pasado y Presente, 2012).

Concha Pallarés is a PhD in Contemporary History at National Distance Education University (UNED, Spain). Her Thesis Dissertation was entitled "Displaced and Political Refugees in Spain, 1940-1947: The Role of Embassies" (2009).

1. From the extensive number of scholarly works of recent vintage, the following might be consulted: Paul Preston, The Spanish Holocaust: Inquisition and Extermination in TwentiethCentury Spain, London: HarperPress, 2012; Joan Llarch, Campos de concentración en la España de Franco, Barcelona: Producciones editoriales, 1978; José Manuel Monago, El campo de concentración de Nanclares de la O ca, 1940-1947, Vitoria: Gobierno Vasco, 1998; Javier Rodrigo, Los campos de concentración franquistas. Entre la Historia y la Memoria, Madrid: Siete Mares, 2003; Javier Rodrigo, Cautivos, campos de concentración en la España franquista, 1936-1947, Barcelona: Crítica, 2005; Carme Molinero and others (eds.), Una inmensa prisión. Los campos de concentración y las prisiones durante la guerra civil y el franquismo, Barcelona: Crítica 2003; José Ángel Fernández, Historia del campo de concentración de Miranda de Ebro, 1940-1947, Miranda de Ebro: Edición del autor, 2003; Ángeles Egido and Matilde Eiroa, eds, "Los campos de concentración franquistas en el contexto europeo," Ayer 1, 2005, 11-24; Jon Barriuso, "Camps de Concentració i Unitats Disciplinàries de Treballadors a l'Espanya de Franco," Revista Electrónica del Departament d'Història Moderna i Contemporània, available at http://seneca.uab.es/hmic, accessed 27 november 2012; Adrián Blas, Campo de Gusen. El cementerio de los republicanos españoles, Madrid: Memoria Viva, 2010; Felip Solé and Gregory Tuban, Camp d'Argeles (1939-1942), Barcelona: Cossetania, 2010; Concha Pallarés, "Desplazados y refugiados políticos en España, 
of Spain and an important set of memoirs in which those involved reconstruct their experiences from the moment in which they began their journey through Europe until their arrival at the Pyrenees and their detention. ${ }^{2}$ This marked increase in the research of this topic was also furthered by the passing of the Law of Historical Memory and the declassification of military files in Spain. ${ }^{3}$ When passed by the Congreso de los Diputados (Spanish Parliament) in 2007, this law raised several questions. First and foremost, it recognized the rights of, and establishment of measures on behalf of, those who suffered persecution or violence during the Spanish Civil War and the dictatorship. Secondly, it reinforced the role of the General Archive of the Spanish Civil War in Salamanca, by integrating it into the Centro Documental de la Memoria Histórica (Documentary Center of Historical Memory), also situated in Salamanca. Thirdly, the law was aimed at facilitating access to the central archives of the Ministerio de Hacienda y Administraciones Públicas (Ministry of Inland Revenue and Public Administration), which held an important series of documents pertaining to the Civil War and relevant to the purges suffered by those on the losing side, as well as those of the Ministerio de Defensa (Ministry of Defense), which contains documentation relevant to the summary courts martial carried out during the Spanish Civil War and the dictatorship.

1940-1947. El papel de las embajadas," unpubl. Ph.D. diss., Madrid: Universidad Nacional de Educación a Distancia (UNED), 2009; José Ramón González, "Prisioneros del miedo y control social: El campo de concentración de Castuera," Hispania Nova 6, 2006, available at: http://hispanianova.rediris.es/6/dossier/6d004.pdf, accessed 2 December 2012.

2. Robert Belot, Aux frontiers de la liberté, S'évader de France sous l'occupation, Paris: Fayard, 1998; Patricia Bes, Historie et mémoire de évasions vers l'Espagne sous l'occupation (19401944), Toulouse: University of Toulouse II, 2001; Emilienne Eychenne, Pyréneés de la liberté. Les évasions par l'Espagne 1939-1945, Paris: Private Edition, 1998; Ciryl Penna, Escape and Evasion, London: United Writers Publications Ltd. Cornwall, 1987. Some key memoirs include Michael Foot and J. L. Langley, Escape and Evasion. 1939-1945, London: Book Club Associates, 1979; The Earl of Cardigan, I Walked Alone: An Escape Through France in 1940, London: Routledge \& Kegan Paul Ltd, 1950; John Thomas, No Banners: The Fabulous Story of the Legendary Newton Twins Who Waged a Private War against the Nazis, London: W.H. Allen, 1955; Sherrie G. Ottis, Silent Heroes: Downed Airmen and the French Underground, Lexington, KY: UP of Kentucky, 2001; Vincent Brome, The Way Back, London: The Companion Book Club, 1958; Pierre Sandahl, Miranda ou l'evasion par l'Espagne, Paris: La Jeune Parque, 1945; Marcel Vivé, Les évadés de France a travers l'Espagne, guerre 1939-1945, Paris: Editions des écrivains, 1998; Albert Pauly, Du Perron a Picadilly, Bruxelles: Editions Livres du temps, 1965; Andre Pechereau, Les vendanges de Miranda: Temoignage, 19401944, París: Le Cercle d'or, 1983.

3. An example of the investigation of military documents is Francisco J. López, "Fondos documentales conservados en el Archivo General Militar de Guadalajara," Cuadernos Republicanos 55, 2003, 85-100; Francisco J. López, "Las fuentes: los archivos militares," in Ayer 1, 2005, 27-49. 
Among Spanish concentration camps, Miranda de Ebro (in the province of Burgos) is unique, not only because prisoners from the northern front of the Spanish Civil War were detained there, but mainly because it was also used as a detention camp for refugees fleeing from the Nazi terror during the Second World War, especially between 1940 and 1943. The following pages focus on this little known aspect of the Miranda camp's operation during the Second World War, in other words, on the workings of a concentration camp located in a country that was identified as "non-belligerent" and, in theory, neutral with regard to the worldwide conflict that began in 1939.

The camp held several waves of soldiers, officers, and pilots, but also civilian women and men. As well as this, Jews were confined there who had been forced to flee from the Nazi-fascist advance through Europe in order to save their lives, intending to leave the continent by way of Spain and Portugal. Many crossed the Pyrenees despite the dangers that this entailed, given that, on the other side of the mountains, Francisco Franco (1892-1975), a fierce ally of Hitler, was in power. And many of these refugees were arrested at the Franco-Spanish border, in Catalan cities nearby, in rural areas of Navarre and the Basque Country, and even in places close to Portugal, and were then interned in the concentration camp in Miranda del Ebro. In this article, we shall primarily concentrate on analyzing the presence of French and British inmates, citizens of Allied countries, in Miranda, leaving it to others to investigate the fate of Jews and others who spent time in the camp in greater depth. We shall leave aside other aspects of the general framework of Spanish politics and its ties with the Axis during the Second World War, which have been studied in detail by various authors. ${ }^{4}$

$* * *$

The advance of German soldiers who marched across Europe between 1939 and 1944 paralleled that of thousands of evacuees, fugitives, deportees, prisoners of war, and refugees seeking to escape from the terror unleashed by Nazi occupiers and their aiders and abetters. As the German army advanced, masses of people streamed across the continent, looking to escape by any form of transport or on

4. It is impossible to list all books about the topic of Franco and Hitler's relationship during the Second World War here, but mention should be made of some of the more recent English works: Wayne H. Bowen, Spain during World War II, Columbia, MO: U. of Missouri P., 2006; David Wingeate Pike, Franco and the Axis Stigma, Houndmills: Palgrave MacMillan, 2008; Stanley Payne, Franco and Hitler: Spain, Germany and World War II, New Haven, CT: Yale UP, 2009. See also Massimiliano Guderzo, Madrid e l'arte della diplomazia. L'incognita spagnola nella seconda guerra mondiale, Firenze: Manent, 1995. 
foot. This was extremely difficult in occupied continental Europe. ${ }^{5}$ From 1940 on, flight was only viable through Switzerland and Spain; the Spanish route was usually preferred, as it led directly to Portugal and Gibraltar, from where there was some hope of reaching Great Britain, North Africa, or elsewhere. Escape routes might run from Holland, Belgium, and northern France, or from Poland through Czechoslovakia, Hungary, Yugoslavia, Italy, Switzerland, and unoccupied France to Spain. These routes were complex, involving, in some cases, crossing up to five borders clandestinely before reaching Portugal or Gibraltar. Their existence and course are known from statements made by officers and soldiers to the security forces that controlled the Spanish borders. ${ }^{6}$ Several Polish officers reported having made an unusual journey leading from Poland through Romania and Hungary to France. The British captain Ian Garrow had escaped from a field near Normandy in June 1940 and organized the passage of French, Belgian, and British soldiers from occupied France to Spain. Special urgency in organizing these trips applied to the shepherding of pilots, doctors, senior officers, and secret service agents, whose usefulness for the war was of vital imporance. ${ }^{7}$ Some paid up to 30,000 francs for visas, although money was not the only problem faced by such travelers. Getting a French exit visa was extremely difficult in the area controlled by Marshall Petain's regime in Vichy. Jews had to overcome the added difficulty of Paragraph 19 of the Franco-German armistice that ordered their repatriation to German territory. The Jews who arrived in Spain were of all nationalities: Poles, Czechs, Hungarians, Russians, and Turks, and many of them had been living in France since the 1920s. The great wave of Jewish escapees occurred in August and September 1942, after the deportations began in earnest in mid-July with the Winter Velodrome raid against Jews in Paris. Thereafter the number of Jewish families increased and, as a result, Spanish policy tightened the border. ${ }^{8}$

The bureaucratic obstacles refugees faced were numerous. Portugal required from those who wanted to enter the country an exit visa, issued in the country of

5. Details and statistics on population movement can be found in Eugene M. Kulischer, Europe on the Move: War and Population Changes, 1917-1947, New York: Columbia UP, 1948. Malcolm J. Proudfoot, European Refugees, 1939-1952: A Study in Forced Population Movement, London: Faber, 1957; Michael R. Marrus, The Unwanted: European Refugees in the Twentieth Century, Philadelphia, PA: Temple UP, 2002.

6. See Arxiu Historic Girona [from here: AHG], Govern Civil, File number 254, Bordiers Files (1940-1942).

7. Some examples can be found at The [British] National Archives, Foreign Office, Kew, Surrey, files $371 / 49600$.

8. AHG, Bordiers Files, 1940-1942, File number 254. Varian Fry, Surrender or Demand, New York: Johnson Books, 1997. 
origin, entry and exit visas from Vichy France, Spanish transit visas, and entry and exit visas for the final destination, along with a train or plane ticket showing the same. Since July 1940, M19, a section of the British Intelligence Services, cooperated with the secret services of European governments-in-exile in London in the organization of escape networks in order to add military and other refugees to the Allied ranks as quickly as possible. ${ }^{9}$ Sometimes M19 acted jointly with agencies such as the Belgian State Security and Polish Resistance Intelligence Services, which had their own networks. ${ }^{10}$

Throughout the Second World War, the Franco government insisted that it was neutral and non-aggressive, but its linkage to the Axis and its geographic location led to its inevitable hampering of this forced migration process. The Spanish consulate in Marseilles provided transit visas to any person holding a visa for Portugal; it carefully screened for members of pro-Republican political parties or opponents of the Franquist regime. Meanwhile, on 11 November 1940, Spanish transit authorizations were further restricted as a result of the armistice with France and the agreements between Reichsführer SS Heinrich Himmler and the Spanish security chief and eventual ambassador in Berlin, Count Mayalde (1904-95), regarding cooperation between the Gestapo, the Spanish police, and other intelligence agencies of both countries. ${ }^{11}$ The aim of these agreements was to repatriate the maximum number of combat-age Axis citizens while detaining Allied citizens in order to reduce the numbers of British and, eventually, US troops as much as possible.

$* * *$

In the last trimester of 1939, the Spanish government began to be confronted with a flow of Allied refugees across the Pyrenees, but it did not take any action until

9. Francis H. Hinsley et al., British Intelligence in the Second World War, Cambridge: Cambridge UP, 1990; Michael Alpert, "Operaciones secretas inglesas en España durante la Segunda Guerra Mundial,” Espacio, Tiempo y Forma. Serie V: Historia Contemporánea, vol. $15,2002,455-72$.

10. Jean Fosty, "Réseaux belges," Cahiers d'histoire de la Seconde Guèrre Mondiale 2, 1972, 79-111; Colonel Rémy, Le refus. Mémoires d'un agent secret de la France Libre, Paris: France Empire, 1998; Hector Romantxo, Han pasado los Pirineos, Perpignan: N.p., 1958; Juan Carlos Jimenez de Aberasturi, Vascos en la II Guerra Mundial. La red Comète en el Pa's Vasco (1941-1944), San Sebastián: Txertoa, 2004; Airey Neave, SATURDAY at M.I.9: The Classic Account of the WW2 Allied Escape Organisation, London: Pen and Sword, 2010.

11. Raffael Scheck, "The Prisoner of War Question and the Beginnings of Collaboration: The Franco-German Agreement of 16 November 1940," Journal of Contemporary History 2, $2010,364-88$. 
the occupation of France increased their number dramatically. Sir Samuel Hoare (1880-1959), the British ambassador in Madrid, calculated that roughly 30,000 to 40,000 people eluded the border patrols and survived the dangers of the mountains, travelling in severe weather, on foot or by bicycle, alone or with passeurs. ${ }^{12}$ While in Spain the harshest period of the Franquist repression and prosecution (1939-1942) was taking place, about 16,000 (and thus perhaps half) of the refugees were unable to reach the escape networks, and were detained by the authorities and taken to the camp at Miranda. ${ }^{13}$

Although the refugees could not trust pro-Nazi Spain, they knew it was almost the only country that offered any chance of escape from Nazi-occupied Europe. And so, it became a mortal trap en route to freedom for the citizens of 67 states. Among them, French, Canadians, Germans, Poles, Belgians, English, Dutch, Americans, and "stateless" formed the bulk of the inmates, since they represented $94 \%$ of the total number of foreigners interned at Miranda. This camp population was made up of groups from highly varied social backgrounds, but they had the goal of escaping from the Nazis and a desire to stay alive, while some aimed to join the democratic armed forces.

The Miranda camp operated for a period of ten years, from 1937 to 1947, which decade can be roughly divided into two clearly different stages. During the first stage, until the summer of 1940, prisoners of the Spanish Civil War were confined there, from whom the $75^{\text {th }}$ Disciplinary Battalion of Prisoner Workers was formed. The second stage began with the arrival of foreign prisoners in the autumn of 1940 . From 1942 on, it was populated solely by refugees from $\mathrm{Nazi}$ Europe and prisoners who had served in the former International Brigade during the Civil War. The latter started to arrive from the camp at San Pedro de Cardeña (Burgos province) at the end of 1940. Given the range of nationalities as well as the presence of stateless people, the camp was divided into two groups: the German Group (which included a subgroup of collaborators, see below) and the Allied Group. ${ }^{14}$

The profile of those detained and interned at Miranda varied according to the time frame in question and reflected the chronology of the Second World War's

12. This was the name the refugees gave to the guides or companions who helped them cross the Pyrenees, either voluntarily or for a fee (see Gisèle Lougarot, Dans l'ombre des passeurs, Bayona: Erkalanean, 2004; Josep Calvet, Les muntanyes de la llibertat, L'Avenc: Barcelona, 2008).

13. The source of the number of detainees comes from Archivo General Militar de Guadalajara [from here: AGMG], Fondo de Miranda de Ebro, Depósito de Concentración de Miranda de Ebro [from here: DCME], Number of foreigners detained from 1940-47.

14. AGMG, DCME, Box 160, Regulations and Incidents. 
battles. From May 1940 until November 1942, French, British, Polish, Czechoslovakian, Yugoslavian, Belgian, Dutch, and Luxembourgian troops arrived as well as young French civilian men who, after the humiliation of their country's rapid defeat, were trying to reach Great Britain to join General de Gaulle's troops. ${ }^{15}$ Central-European Jews who had settled in France in the 1920s and 1930 s, along with those from Germany, Austria, and Czechoslovakia, arrived en masse in August and September of 1942, fleeing deportation. In August of that year, mainly Canadian soldiers escaping from the failed Dieppe landing and Allied pilots shot down over occupied zones started to appear at the camp.

The Allies' simultaneous landings in Morocco and Algiers led the Germans to invade Vichy France in November 1942. As a result, soldiers, "burnt-out" resistance fighters, informers to the Secret Services of France, Belgium, and Poland, together with escaped concentration camp prisoners and civilian refugees in general joined the men and women of Belgium, France, and Holland who, after refusing to become part of Germany's forced labor programs (in French called Service du Travail Obligatoire or S.T.O.), fled to Spain. For many, joining the "Resistance" or traveling via Spain to North Africa to enlist in the Free French forces were conscious acts of rebellion against the enemy. ${ }^{16}$

At Miranda, the largest number of arrivals - but also of departures - was recorded in the first months of 1943. At the end of 1943, the total expenses resulting from foreigners at Miranda reached 5,813,441.90 pesetas, to which the expenses of Jaraba camp for officers, a total of $241,435.26$ pesetas, had to be added. ${ }^{17}$ This amount was so high that the Ministry of the Army had to request extraordinary credit to cover the costs for the fugitives' stay.

From 1944 on, the internee profile changed, as the Nazis and their allies beat the retreat. German customs officers, French and Belgian collaborators, and, in 1945, Nazi soldiers and civilian politicians fleeing from justice began to arrive. The camp was closed at the beginning of 1947 after transferring the remaining Europeans to various Spanish prisons; among them, there were no longer any members of the Allied armed forces.

Civilians and military personnel had different fates. Civilians of means, including women and children, or those who had economically and politically solvent sponsors, were permitted to stay in Spain on probation until the documentation

15. AHG, Civil Government, Border Files, 1940-1942.

16. See Ottis, Silent Heroes; Sandahl, Miranda ou l'evasion par l'Espagne; Albert Pauly, Du Perron a Picadilly.

17. AGMG, DCME, Box 158, note of 5 May1944, Ministry of the Army. 
they needed to leave the country could be arranged. Those who had neither means nor sponsorship were detained at Miranda camp without being indicted for any crime until their documents could be arranged. Regulations required military personnel to be disarmed and held at the detention camp designated by the Ministry that corresponded to their branch of the armed forces: Army, Navy, or Air Force. Non-commissioned officers and troops were held at Miranda de Ebro, while generals, chiefs, and officers went to Jaraba and Alhama de Aragón (both Zaragoza province), although not all high-ranking officers were sent to these facilities, where the conditions and food were better than at Miranda. ${ }^{18}$

Distinctions were also made between those of military age and those who were not, and between citizens of nations that were enemies of Germany and those of nations that had been subjugated by Germany, such as Czechoslovakia and Poland. All of them went to Miranda, but the length of their stays as well as their final destinations varied. The destinations of the stateless were often uncertain and those under German jurisdiction were dealt with by the International Red Cross. ${ }^{19}$

The British Embassy, which was among the most concerned with detainee movement, estimated that 3,500 people were confined there in 1942, despite the fact that it had a maximum capacity of $2,000 .{ }^{20}$ Prior to the occupation of France, the estimated population of the camp was 1,389 , but massive flight by German inmates in the summer of 1940 dispersed an unprecedented number of people. A secret document from the Sixth Regional General Headquarters, which was responsible for the camp, tallied the presence of 3,406 prisoners, 534 of whom were generals, leaders, or officers, and approximately 425 were noncommissioned officers in late $1942 .{ }^{21}$ All of them were housed in twenty twohundred-man barracks designed to room 2,200 men. Until the end of 1942, one of those barracks was used to house prisoners with contagious diseases and another was for those considered dangerous due to their moral conduct or their political significance. The human avalanche that arrived made this separation unsustainable, which thus led to added risks for the detainees when ill inmates mixed with healthy ones.

18. AGMG, DCME, Boxes 150-160.

19. Memoranda $n^{\circ} 70,29$ January $1943 ; n^{\circ} 78,30$ April 1943. Department of Security of the Ministry of the Interior. See also José $\mathrm{M}^{\mathrm{a}}$ Espinosa de los Monteros and Concha Pallarés, "Miranda, mosaico de nacionalidades: franceses, británicos y alemanes," Ayer 1, 2005, $153-87$.

20. AGMG, DCME, Box 140. Reserved note, 24 December 1942.

21. AGMG, DCME, Box 140, Secret informative note, 29 December 1942. 
The crowding in Miranda exceeded all the provisions of the Franquist authorities, who were forced to outfit other facilities, including the camps at Jaraba (where army generals, leaders, and officers were lodged), Alhama de Aragón (pilots), Sobrón and Nanclares de la Oca (Álava province), Molinar de Carranza and Urberuaga de Ubilla (Basque region). The internment of foreign refugees was not just an issue for the Ministries of the Interior or the Army to deal with, for it became a priority for the Ministry of Foreign Affairs when foreign embassies started protesting about these illegal detentions that violated their citizens' international rights. The Allied governments saw these detentions as nearly an act of war in that they impeded the regrouping of soldiers and officers with their respective armies and thus favored the Axis. The internment of foreigners in Miranda de Ebro became a problem for Franquist foreign policy.

It might be asked if Miranda de Ebro served as an outlying concentration camp included in the Nazi network of camps designed for various purposes in other European countries outside Germany's borders (as in occupied France, Belgium, or the Netherlands, the Generalgouvernement Polen or the Reichskommissariat O stland). This was evidently not the case, but that does not make the camp's position entirely clear with regard to the exact level of authority of the Spanish government over it. Nazi Germans were advising the Spanish Army officials on aspects of administrative and social organization when the camp was created at the height of the Spanish Civil War, when it served the purpose of interning prisoners from the Republican army who had fought on the Northern Front. The pre-war Nazi-German camp model was used at Miranda and Paul Winzer (1908-?), a member of the Gestapo and the SS in charge of reviewing concentration camps in territory conquered by Franco, participated in its design. ${ }^{22}$ By the time the unexpected transition from Civil War camp to World War camp occurred, the Spanish authorities boasted of years of experience managing these facilities and no Nazis further participated directly in its direction. However, the German Embassy in Madrid routinely intervened in the transit of refugees. This included issuing various documents and permits concerning exit visas and repatriations, especially of those the Nazis considered "subjects," such as Czech and Slovaks, Poles, Germans, or French. Such refugees were in effect placed under the strict supervision of German diplomats and the camp's management acceded to all their requests, including the

22. Christian Goeschel and Nikolaus Wachsmann, "Before Auschwitz: The Formation of the Nazi Concentration Camps, 1933-9," Journal of Contemporary History 3, 2010, 515-34. Winzer escaped to Argentina after the Second World War. 
repatriation of Czechoslovakians and Poles, despite the protests of British and other diplomats. ${ }^{23}$

Altogether, nonetheless, the Miranda Concentration Camp served as an internment center for civilians, troops, and officers who were fleeing from Nazi persecution, which led, in the long run, to the survival of thousands. This even if the inmates were released slowly and late, forced by threats made by the British and North-American governments to cut off supplies of raw materials, or to designate Spain a belligerent nation, if the Spanish government persisted in pursuing measures which were favorable to Hitler. The Spanish government, consequently, acted with great ambiguity, given that it handled the destination of the refugees according to the political pressure applied, on the one hand, by the Allies and, on the other, by the Axis. It acted in a manner that was cynical and to its own benefit, following the ideological guidelines laid down by the regime that had identified with those of Nazi Germany ever since the coup d'état of 18 July 1936, which sparked off the Spanish Civil War, which almost immediately was backed by Hitler both economically and politically. ${ }^{24}$

An analysis of the French and British inmates of Miranda de Ebro yields a good illustration of the profile and condition of the refugees who fled to neutral Spain. The influx of British nationals began around the time of the French government's armistice with Germany and the division of France into two in the summer of 1940. Individually or through the newly formed escape networks, some British officers managed to hook up with their units again and return to Great Britain, but many failed to reach the escape from Dunkirk on time. During the initial days of the occupation, some of those left behind wandered the streets of Paris in uniform, while others took refuge with French families in the north. Crossing occupied France held serious dangers, which many were able to avoid thanks to the secret services, the underground escape networks, and certain consulates in the Vichy-ruled territory, such as the ones in Lyon and Marseilles, which not

23. Archive of the Spanish Ministry of Foreign Affairs [from here: AMAE in the rest of the article], Dossier R-2182, File 7. Note from the British government, December 1942.

24. See Ángel Viñas, La Alemania nazi y el 18 de julio, Madrid: Alianza Editorial, 1977; and Ángel Viñas, Franco, Hitler y el estallido de la Guerra civil: antecedentes y consecuencias, Madrid: Alianza Editorial, 2001. Stanley Payne's Franco and Hitler repeats some of the myths which have now been debunked by the historians who have consulted the newly available primary sources in the archives, which are now freely available for consultation. 
only acted as aid institutions but also provided support for individual and group escapes. ${ }^{25}$

Some were interned in prison camps in France and Germany and others escaped from places of internment near Marseilles, such as Saint Hyppolite or the fortress of Saint Válery de Caux. In some cases, there were individual escapes, such as that of the Earl of Cardigan, whose memoirs narrate his journey from his escape in June 1940 from a German concentration camp in Boulogne to his arrival at Miranda de Ebro in August, his subsequent liberation in September thanks to the mediation of the British Consulate in Barcelona, and his transfer to the embassy in Madrid from where he traveled to Gibraltar. ${ }^{26}$ Another escaped soldier after the defeat at Dunkirk was Peter Janes, interned in Saint Válery de Caux with other British soldiers. ${ }^{27}$ Together with a group of escapees organized by the "Pat O 'Leary" escape network, he began his escape to Spain on 1 September 1941, but was detained at the border and taken to Miranda de Ebro.

In general, it was the British military who were first admitted into Miranda de Ebro in June 1940. At first, they declared to be "Canadian" and "civilians," although they later rectified and declared themselves their true nationality and military status. ${ }^{28}$ These troops and some civilians had crossed the border from France into Catalonia, Andorra, Navarra, Aragón, or Güipúzcoa (Basque region), the routes most commonly used by the escape networks, because they presented a direct path to the Allied consulates in northern cities such as Barcelona or Gerona, where vice-consuls Gardiner Whitfield and Reginald Rapley did whatever possible to assist the groups requesting help. Those unlucky enough to be detained generally spent a few hours or days in nearby prisons, like the Pamplona Provincial Prison or the one in Irún prison. From there, they were moved to institutions the

25. Donald Darling, called "Sunday" in MI 6 code, coordinated the actions of these networks from Madrid and later from Lisbon and Gibraltar. The link in the British Embassy in Madrid was Michael Creswell, called "Monday" in code, who held this responsibility from 1941. On the British Secret Service and the escape networks, Foot and Langley, Escape; Jean Pierre Azema and François Bedarida, La France des années noires, vol. 1: De la défaite à Vichy, Paris: Seuil editions, 2000.

26. Earl of Cardigan, I Walked Alone.

27. Keith Janes, Conscript Heroes, available at http://www.conscript-heroes.com/, accessed 27 December 2012. This book tells the adventures of his father, Peter Janes, from the defeat at Dunkirk until his return to Great Britain.

28. AGMG, DCME, Box 140. Personal. Accounts of internees (Accounts of people admitted and internees), 1940. Some documents on these "false" Canadians in AMAE, Dossier R-2182, File 125: "Clandestine immigrants from France." That they were British is evident from the rest of the personal information they gave to the authorities, as well as the fact that the British embassy dealt with their freedom permit. 
authorities had agreed to, or to Miranda de Ebro to await the completion of the necessary administrative proceedings with the Spanish authorities that would allow them to reach Gibraltar.

British citizens arrived constantly, although their number was low in comparison to other nationalities such as the French, or the bulk of the group that declared itself Canadian. Throughout 1941 the trickle of soldiers who were interned consisted of soldiers who came from German concentration or POW camps and occupied countries such as Poland and France (the camps at Drancy, Gurs, Orleáns, or Saint Dénis). This was the case of Charles Gillion, coming from Gurs, who arrived in France with the British Expeditionary Force in $1940 .^{29}$ After the disaster at Dunkirk, he did not succeed in joining the great majority of his companions, and was taken prisoner by the Germans. He escaped from the camp where he was interned, but was detained by the Civil Guard when he crossed the Spanish border at Catalan Figueras in February 1941. Until December of that year, he was a forced laborer in the 75th Workers Battalion of Palencia, when he was transferred to the Miranda camp.

The pilots who had been shot down over German territory as a consequence of increased Allied air actions over the continent in 1942 and 1943 formed a special group. Bombers' actions were risky and planes were often downed; many of the pilots parachuted to earth after their planes had been brought down. This circumstance, the lengthy time needed for their training and Great Britain's defensive need for these professionals led British authorities to consider it a priority to get this airforce personnel back. Because air combat was a decisive factor for British military strategy, the MI9 and the Comete network saw to getting them back into active service by locating the escaped or detained pilots in order to return them in as short a time as possible. One of them, Michael Gordon, an aviation lieutenant shot down over Cologne, crossed over to France where he was taken prisoner, but managed to escape and reach Barcelona in June 1942. He was interned at Miranda that same month. ${ }^{30}$

British civilians and armed forces' deserters also arrived. Identifying civilians was complicated because they lacked identity papers and locating information that proved who they were and where they were from was not easy. In these cases, the Red Cross took care of their repatriation since the embassies often considered the data provided to be untrue and refused support. In times of population movement and war, it is not unusual for spies or people with shady dealings to

29. AGMG, DCME, Box 54, File 5919.

30. AGMG, DCME, Box 48, File 5185 . 
mix in with military personnel and honest civilians. In any case, the average detention time for an English-speaking civilian refugee was between four to six months, and the stay at Miranda de Ebro about three months. ${ }^{31}$ Together with this type of internee, there was also a dwindling number of old International Brigade members of the Spanish Civil War, whose advantage over the other international detainees was that they had not lost their nationality for fighting on the Republican side in the Spanish Civil War.

The detentions, as we have previously pointed out, mostly occurred on the border with the Pyrenees, although they could take place anywhere in Spain, especially in the northern provinces of Catalonia, the Basque Country, and Navarre, and on the border with Portugal. Mostly, it was the Guardia Civil (the paramilitary internal security police) who carried out the arrests and identified the detainees. When it was found out that they were foreigners, they were taken to the camp at Miranda. The Portuguese police returned to the Spanish authorities British citizens who had crossed the border illegally. Despite its traditionally friendly ties with Great Britain, the Portuguese government led by the dictator Antonio Oliveira de Salazar (1889-1970) and the Franco government had signed several agreements related to defense and cooperation between the two nations in the face of the world war, forming an "Iberian Bloc." That is why the Portuguese returned fugitives from Spain, even though they were foreigners unrelated to anti-Franquist opposition activities. Louis Denis, for example, was handed over to the Spanish police in Fuentes de Oñoro (Salamanca province), then taken to the prison in Ciudad Rodrigo and subsequently to the camp at Miranda in January 1942. ${ }^{32}$ He had managed to escape from a German prison camp in Belgium in September 1941 and reached Vichy France, but was imprisoned in Portuguese territory, when he was on the verge of successfully completing his route to freedom.

Overall, British and American soldiers stayed at Miranda a shorter time than people from other countries. The British embassy in particular was very skilled at the identification process, as was the British group leader within the framework of the camp's organizational structure. ${ }^{33}$ Protocol accepted one's "word of honor" regarding British nationality and the recognition of two officers as valid. ${ }^{34}$ The

31. AGMG, DCME, Box 153, Liberated Lists.

32. AGMG, DCME, Box 33, File 3624.

33. AGMG, DCME, Box 153, Liberated.

34. AGMG, DCME, Box 140, List of names, nationality, age, and military rank, which are submitted as documentation and sworn declarations by two officers of the same nationality, 19 February 1943. 
treatment they received at Miranda or the spas near Alhama de Aragón and Jaraba was also different from that given to the other nationalities. Although subject to the arduous conditions of camp life, bad food, poor hygiene, and the frustration of being held while decisive battles were being fought on the continent, the British military benefitted from a greater margin of freedom, especially those in Alhama and Jaraba, where the higher-ranking officers were held. But the preferential treatment given to British nationals was due in part to the low British participation in escapes, protests, and other actions against those in charge of the camp. An example of this was the refusal to join the hunger strike promoted by the Polish group of inmates, an action which resulted in the improvement of conditions and the release of certain classes of prisoners. ${ }^{35}$

But the key explanation for this better treatment was the pressure on the Franco government by Allied diplomats, and the threat that the supply of raw materials that Spain lacked would be cut off after an Allied victory in the war. Meanwhile, the governments of the countries of occupied Europe were either exiled or supported the Axis: They were in no position to exert any influence to prevent mistreatment or to liberate their citizens as the British or Americans could. Therefore, for inmates hailing from much of continental Europe it was the Red Cross that advocated their release. There were even prisoners who had to find support in former diplomats and unofficial embassies, like the Czechs whose only possibility to save their lives was by seeking the aid of Zdenko Formanek, a former Czechoslovakian minister in Madrid and the unofficial representative of the Czech government in London. ${ }^{36}$

The priority for all of them was to get out of Miranda and Spain to reach free territories and get away from the possible threat to their existence in a country with similar interests to those of the Axis, and with economic and political problems related with the Spanish post-Civil-War context. Bureaucratic complications and delays in processing files, in many cases instigated by Franquist institutions, led London and Washington to authorize actions by their intelligence service to spring detainees from internment and even to support fugitives planning individual escape. Officially, liberation of inmates was to ensue when there was no record of accusations and an embassy offered protection. Once released, British soldiers and citizens were moved from Miranda to Madrid and from there to

35. AGMG, DCME, Box 150, Information sheet from the camp's Civil Guard Information Service, 23 February 1943.

36. On this subject, see Antonio M. Moral, Diplomacia, humanitarismo y espionaje en la Guerra civil española, Madrid: Biblioteca Nueva, 2008. 
Lisbon or Gibraltar, where they were debriefed by MI9 in search of information that would serve the British cause. The British ambassador Hoare and his American counterpart, Carlton J.H. Hayes (1882-1964), were involved in these operations, although, at times, they rejected the actions of MI6 and MI9 due to their position as ambassadors; thus, Hayes rejected certain espionage activities. The American ambassador thought that such actions jeopardized the efforts being made through diplomatic channels to speed up the release of the internees and caused Franco's government to distrust the United States and Great Britain. ${ }^{37}$ Both ambassadors were very active pressuring the Ministry of Foreign Affairs and the Ministry of the Army to get their nationals released. The basic argument used to speed up the processing of release documents was that Spain as a neutral country was not respecting international agreements on refugees, exiles, and fugitives. Their threats led to a change in regulations for foreigners and the eventual liberation of those older than 40 and younger than 18 . Nevertheless, the ambassadors only managed to achieve this in large numbers after 1942, when the Spanish government found itself in a difficult situation following the Allied landings on the coasts of North Africa. Repatriations, then, were very tepid in 1940 when only 132 British prisoners were released, but they increased considerably in 1943 with 2,223 individuals being liberated and 5,026 in $1944 .{ }^{38}$

As of that year, there were hardly any British citizens left in the camp and those who arrived, mainly civilians, barely stayed a few weeks until they were identified and released. One of the last British internees was Sub-Lieutenant Philipp Daniens Pirot, shot down over French territory in February $1944 .{ }^{39}$ Hidden in France until he crossed over into Spain, he was detained in Guipúzcoa on 6 June and interned at Miranda until 1 July when he was freed.

\section{$* * *$}

French citizens were the most numerous group from the time they started arriving in 1940. In that year, 736 people declared themselves to be French. ${ }^{40}$ These

37. For the role of the embassies and an in-depth analysis of the international component of the Miranda camp, see Pallarés, "Desplazados y refugiados." See also Carlton J. H. Hayes, Wartime Mission in Spain, 1942-1945, New York: The Macmillan Company, 1945; Denis Smyth, Diplomacy and Strategy of Survival: British Policy and Franco's Spain, 1940-1941, Cambridge: Cambridge UP, 1986; Keith Jeffery, MI6: The History of the Secret Intelligence Service, 1909-1949, London: Bloomsbury Publishing, 2011.

38. National Archives (Kew), Foreign Office, 371/39681.

39. AGMG, DCME, Box 30.

40. According to data from AMAE, Dossier R-2182, file 6 . 
numbers would grow in the following years. The occupation of France, from the armistice of June 1940 until the final defeat of the German forces that followed the Allied landing in Normandy of 1944, elicited diverse reactions among the civilian population. A minority joined the resistance, a risky choice, while the majority accepted the new situation. A few chose to leave France in order to join de Gaulle's forces. This last group usually decided to cross the Pyrenees and travel across Spain to reach the free zones as quickly as possible. Some traveled alone or in small groups mapping their own route, but others joined escape networks that offered safer paths out of France. These included the Maurice network, the Renard network, the Françoise, while some were organized by anti-Franco political parties and labor unions such as the Basque Nationalist Party (PNV) and the organization created by the anarchist Paco Ponzán (1911-44), known as the Pat O'Leary network. ${ }^{41}$ The French and other foreigners were also aided by Spanish men and women who, for money, out of solidarity, or because they hated the Germans, were willing to help these refugees find safe routes to elude police controls. However, escape routes to Spain via the Atlantic Pyrenees were closely watched by Nazi border controls, and the routes through the middle range of Pyrenees of Lérida, Andorra, and Figueras, or the Basque routes through the Pyrenees of Navarre, Fuenterrabía, or Irún were equally well guarded by the Spanish Civil Guard or the secret police, through which many were detained at the border.

These prisoners were then taken to Spanish prisons (at Gerona, Barcelona, Zaragoza, Huesca, or Pamplona) or interned at the camp at Miranda de Ebro. According to Robert Belot, 40,000 foreigners entered Spain between 1940 and 1945, of whom 30,000 were French. ${ }^{42}$ Of these, 8,000 had been detained by April 1943 with $37 \%$ going to the camp at Miranda de Ebro, 29\% to prisons, $14 \%$ to spas that had been refurbished for prisoner detention, and $20 \%$ to hotels reassigned for the same reason.

When they were detained and transported to the Miranda del Ebro camp, many of them declared they were Canadian, American, or Belgian, for fear of forced repatriation and of being considered "deserters" or "Gaullists." ${ }^{43}$ By the

41. Pilar Ponzán, Lucha y muerte por la libertad. Nueve años de guerra: 1936-1945, Barcelona: Tot Editorial, 1996; Antonio Téllez, La red de evasión del grupo Ponzán, Barcelona: Virus, 1996; Juan Carlos Jiménez de Aberasturi, Vascos en la Segunda Guerra Mundial: la red Comète en el Pa's Vasco (1941-44), San Sebastián: Txalaparta, 1999; Jean Rémy, Le réseau Comète: la ligne de demarcation, París: Librairie Académique Perrin, 1996.

42. Robert Belot, Aux frontiers de la liberté, S'évader de France sous l'occupation, 292-93.

43. These were some accusations that Spanish authorities leveled against the French soldiers. 
early months of 1941, an agreement had been reached between France and Spain to repatriate all persons detained within a $5-\mathrm{km}$. radius of the French border, and those who had arrived without a passport or visa. This is what happened to hundreds of young people like Paul Tournadre, who arrived in Rosas (Gerona) on 30 October 1940 and, from there, was transported to the camp in Cervera (Lérida), and interned at Miranda in November. In July 1941 he was returned to France. ${ }^{44}$ The French embassy, loyal to the Vichy regime, did not help them and it was the British who had to see to the French who declared they were British, American, Canadian, or Belgian, in order for them to receive protection and obtain a rapid release. But false identities were often quickly detected when data was compiled in the camp registry; when detected, fugitives were reassigned their true national identity and then placed in the care of their corresponding embassy. An example of a "false Canadian" was Valentin Bernadicou Peyret, who admitted as having been born in Toulouse (France), and being a fugitive from the camp in Gurs. ${ }^{45}$ The benefits of identifying oneself as Canadian (and being recognized as such) were well-known to the internees: Canadians were liberated relatively quickly, whereas French nationals only left the camp after a much lengthier process, mediated by the Red Cross. Other Frenchmen declared they were Belgian, such as André Auprince, who confessed that he had declared this as his country of origin for fear of repatriation to France. ${ }^{46}$ Among those considered French were the children of Spaniards originally from such areas as Levante, Andalusia, and the Basque Country, who had emigrated to France between the years 1910-20. Among them was José Berenguer, who had emigrated to France with his family when he was 17 months old. ${ }^{47}$ He was an infantry sergeant in the French army, and a hospital nurse, captured by the Germans in Strasbourg and interned in the POW camp Stalag 5 B. From there he escaped, crossed Switzerland and France, and entered Spain in December 1942 by crossing the Pyrenees in Andorra. Apprehended by the Spaniards, he was admitted to Miranda at the end of the month, but was (somewhat surprisingly) liberated as a result of the British Embassy's intervention in 1943.

The French fugitives shared space with their fellow countrymen from the International Brigades who had been confined in the camp in San Pedro de

44. We reproduce the same spelling of first and last names that appear on entry records and in personal files (AGMG, DCME, Box 127, File 13968).

45. AGMG, DCME, Box 11, File 1169.

46. AGMG, DCME, Box 5, File 514.

47. AGMG, DCME, Box 11, File 1114. 
Cardeña (Burgos province) since the Civil War. At the end of 1941, these Republican volunteers were moved to Miranda de Ebro, where they were considered a special group. Many had lost their nationality by taking military service for a foreign government and were part of those stateless persons for whom no institution apart from the Red Cross took responsibility. This meant that Brigade members formed a long-term group; despite their numerous complaints to the Ministry of Foreign Affairs regarding their long internment, little changed in their status for years. They often complained about their attachment to the 75 th Disciplinary Battalion along with other foreign residents in Spain who had either fought for the democratic Republic or, although they had not taken up arms, were detained for presumed opposition to Franco's regime. ${ }^{48}$ Among these international internees was Teodoro Francos Martín, nicknamed "Theo," who served in the XI International Brigade ("The Paris Commune" Battalion) and was a member of the 65th Brigade of the Republican Army, which fought in Extremadura and Andalusia. ${ }^{49}$ Transferred to the Madrid prison of Yeserías, he was interned at the Miranda Camp in June 1940 and incorporated into the $27^{\text {th }}$ Workers Battalion. He escaped from the camp twice and was imprisoned in Burgos prison. Through the mediation of the French Red Cross, he finally managed to get out of Spain in order to join up with the Allied forces. As in Theo's case, most French Brigade members at Miranda managed to embark for North Africa in 1943.

From the summer of 1942 there were numerous young men who crossed the border to avoid the Compulsory Work Service (S.T.O.). The objective of the S.T.O. was to obtain a workforce that would participate in the German war effort by working in factories, agriculture, or on infrastructure. Since voluntary recruitment was a failure, in February 1943 the head of the French government, Pierre Laval (1883-1945), decreed that joining the S.T.O. was mandatory for men born between 1920 and $1922 .{ }^{50}$ Therefore, early 1943 became the time of a maximum influx of French fugitives in their early twenties who crossed the Spanish border. Those who tried to avoid their compulsory trip to Germany were liable to arrest;

48. AMAE, Dossier R-1346, File 225.

49. AGMG, DCME, Box 45, File 4946; Interview with Teodoro Francos Martín conducted in Bayonne (France) in July 2003.

50. Bernard Garnier et al., eds, La Main-d'œuvre française exploitée par le IIIe Reich, Caen: CHRQ, 2001; Françoise Berger, "L'exploitation de la main-d'oeuvre française dans l'industrie sidérurgique allemande pendant la Seconde Guerre mondiale," Revue d'histoire moderne et contemporaine, July-September 2003, 148-81. 
if caught, they were interned in the camps at Gurs or Noé, from where they managed to escape to Spain.

Among those who had fled from the S.T.O. and wanted to join the Allies was Henri Lauze Dior, who entered through the Gerona route in May 1943 and was interned at Miranda the following month. According to his statement to the Spanish authorities, he worked in Toulouse as an accountant in an insurance company, and belonged to a group whose objective was to keep young people from being sent to forced labor in Germany by hiding them in woodcutter camps near Pau, where they were safe from the Germans; he added that this group was not political, but rather that "we helped one another to prevent us from being caught for compulsory work." 51

Among the great variety of those escaping France were also Jews fleeing anti-Semitic persecution, especially after what has been called "Operation Spring Breeze," better known as the Velodrome Raid, in July 1942, in which around 13,000 were arrested in Paris. Those who could crossed into Spain, intending to reach Portugal and emigrate to the United States, Mexico, Brazil, and Palestine, although many were detained at the border, or during the train journey to Valladolid, Salamanca, or Badajoz. When they were interned at Miranda, they declared they had fought in the army, or fled from a French prison camp, as did Samuel Bleines, a cavalry soldier. ${ }^{52}$ Upon being wounded at the front, he was admitted to the hospital in Mechelen (Belgium) in March 1940 , but he escaped and was interned again at the camp in Drancy, from which he also escaped. He crossed the Spanish border, intending to go to North Africa. Others hid the fact they were Jewish for fear that Spain would turn them over to the German authorities. Following the decree of 9 February 1943, their situation improved due to the fact that, while they could now identify with the country in which they had resided before the war, they were allowed to declare themselves stateless and, thus, fall under the protection of the Red Cross. The United States Embassy and the American Relief Organization aided them with money and provisions. Some of them arrived in Spain with their wives or girlfriends, which made life more complicated for everyone due to the economic difficulties and the fact that some of the women were placed separately in Spanish prisons.

51. AGMG, DCME, Box 73, File 8032, Declaration to the Investigation Service of the Miranda Camp.

52. AGMG, DCME, Box 14, File 1464. 
Regarding the Jews, the Franco government adopted, as it did in foreign policy, an ambiguous and cynical stance. ${ }^{53}$ Some Spanish Jews from the communities in Ceuta, Melilla, and Madrid had given financial support to the Franquist army and, as a consequence, the government protected anyone that those communities took in and vouched for as non-dangerous persons. However, and despite their assimilation, they were very careful not to exhibit their rites and their social and religious customs in order to avoid suspicion on the part of the authorities. Most of the Jews interned at the camp in Miranda, however, were either returned to Nazi Germany or treated in the same way as the rest of the foreigners.

After the Allied landing in North Africa, the French were helped by the British and US Embassies and the Delegate of the French Red Cross in Spain, Monsignor Boyer-Mas, who became the semi-official representative in Madrid for General Giraud, commander of the Free French in Algeria. Boyer-Mas, who had the support of the Catholic Church and of the leaders of the Spanish Red Cross, organized a network of delegates in charge of distributing the funds arriving from Algeria and the United States to all the penitentiaries where French prisoners were held. The man in charge of the network at Miranda de Ebro was Jean Pierre Bourbon, who handled the financial, food, and health aid for the internees and for those being released. Maltreatment meted out in Spanish prisons of French nationals who had been forced to leave their country due to Nazi occupation was denounced to the Ministry of Foreign Affairs by Boyer-Mas and J.P. Bourbon. ${ }^{54}$ Their complaints included bad food quality, poor hygiene, violence, cold, and disease to which the prisoners were exposed. Boyer-Mas insisted in numerous reports that these were people who had crossed the border fleeing from the S.T.O.

In the spring of 1943 the release of those older than 40 and younger than 18 was ordered. This freed up some barracks although the number of internees was still well over capacity. At the beginning of that year, a report confirmed the

53. The way in which the Franquist regime treated the Jews is beyond the scope of this article, but we should note that sources do not confirm whether or not they were orthodox Jews and we are unable to ascertain their origins. For further information, see Federico Ysart, España y los jud'os en la Segunda Guerra Mundial, Barcelona: Dopesa, 1973; Haim Avni, "The Zionist Underground in Holland and France and the Escape to Spain," in Rescue Attempts during the Holocaust: Proceedings of the Second Yad Vashem International Historical Conference, Jerusalem: Yad Vashem, 1977; Haim Avni, España, Franco y los jud'os, Madrid: Altalena editores, 1982; Antonio Marquina and Gloria Ospina, España y los jud ́os en el siglo XX, Madrid: Espasa Calpe, 1987; David Salinas, España, los sefarditas y el Tercer Reich (1939-1945), Valladolid: Universidad de Valladolid, 1997; Raanan Rein, Franco, Israel y los judíos, Madrid: CSIC, 1996; José Antonio Lisbona, Retorno a Sefarad. La poltica de España hacia sus jud ós en el siglo XX, Barcelona: Riopiedras, 1993; Bernd Rother, Franco y el Holocausto, Madrid: Marcial Pons, 2005.

54. AMAE, Dossier R-2182, File 8, Letter to the delegate of the French Red Cross, Boyer-Mas. 
existence of 3,770 internees for a 2,200-person capacity, and so Boyer-Mas and the British and North-American diplomats requested mass releases. ${ }^{55}$ Little by little, many were liberated and traveled to other areas to join the French or British Armies or to leave Europe for good. According to Foreign Office data, between November 1942 and December 1943, 14,862 French citizens imprisoned at Miranda and other prisons in various Spanish provinces were released. ${ }^{56}$

Even in 1944 French men and women escaping from the Nazi camps continued to arrive in an attempt to save their lives, even if they increasingly anticipated that their side would win the war, especially following the Normandy landings. But even at that time, the Spanish authorities did not stop mistreating them when they were detained: they were exposed to shaving their heads, beatings, bad food, poor hygiene, and deprived from Red Cross aid, that is, the same attitude continued as in previous years when German supremacy had been evident. ${ }^{57}$ Internees made similar complaints to the embassies and to the Red Cross throughout the period that they were interned at Miranda. It is true that there were no executions or incinerations at this camp, like there were in the Nazi camps. However, as seen above, beatings, food rationing, lack of hygiene, provocative and contemptuous attitudes on the part of the Miranda authorities were all frequent, as was another type of mistreatment, namely the deliberate delays in granting release papers. ${ }^{58}$

The decision to flee the Nazi terror for independent countries in Europe was made by those who were fearful of the repercussions of remaining in their residences. They risked their lives, left their property behind, and even made light of the dangers in crossing a neutral country. The course for citizens of many other countries was similar to the one described for the French and the British. Deplorable conditions and prolonged internment periods at the camp, often a year long, were denounced by the diplomats who did not understand why they were being held, nor the reasons for Madrid's attitude, despite its official neutrality in the face of the world conflict. ${ }^{59}$ Meanwhile, Poles, Czechs, or Hungarians received

55. AGMG, DCME, Box 156, Report of 14 January 1943.

56. To be more precise, 5,786 were sent to North Africa via Portugal and 9,076 via Málaga (National Archives [Kew], Foreign Office 371/39681).

57. AGMG, DCME, Box 154-156.

58. See the memoirs cited above.

59. An example of these protest notes in AMAE, R-2182. 9, 1943. 
different treatment because they were considered to be German subjects, and therefore, subject to forced repatriation. Many took refuge in statelessness or falsified their nationality to avoid being returned to German territory and subjected to Nazi wrath. ${ }^{60}$

One explanation that we suggest for the differentiated quality of Franquist policy in this question was the context of economic appeasement and strategic contention that defined Hispano-British relations in the period from 1939 to 1945. The need for raw materials such as petroleum, cotton, and phosphates played an important role in the difficult policy shift of the Spanish government towards neutrality and contributed decisively to the quick release of British, French, and other groups of prisoners from Allied countries as of 1943.

Franco's Spain, although not strictly speaking an ally of the Axis during the Second World War, in practice acted as such owing to the links that had been established with Nazi Germany in Civil War times. Spain became a trap for whoever crossed its border without due precautions and cover. Authorities on what the fugitives called "threshold of freedom" prevented citizens who were against Nazi Germany from rapidly joining military units that continued to fight in various places on the continent. Former detainees fleeing Nazi or French camps as well as simple soldiers or civilians isolated from their circles of support were detained and interned at the Miranda de Ebro concentration camp, ready since 1940 for the circumstances of the second global conflict. Miranda, however, was not only a center for maintaining public order against the avalanche of those recently arrived over the border, but also a resource for the government's foreign policy, which was managed according to political interests, pressure from the Allied countries, and the developments on the fronts. This conclusion seems justified when confronted with the varying criteria applied to the different nationalities regarding the length of their internment, its quality, and the liberation process, even if all of them protested against a detention they considered illicit, excessively prolonged, and beneficial to the Nazi armies.

The history of the displaced European population fleeing due to Nazi occupation offers a broad perspective of study, which must include countries such as Spain that were neutral in the face of the Second World War. When the concentration and internment camps (and those for POWs) of this period are studied, Miranda camp as peripheral support for the Nazi-Fascist concentration camp system is important. Events that led to people being detained at the camp reflected

60. Matilde Eiroa, "Refugiados extranjeros en España: el campo de concentración de Miranda de Ebro," Ayer 1, 2005, 125-152. 
a Europe punished by anti-democratic political systems, shaken by the major forced movement of its population towards survival, and desperate in its quest for freedom.

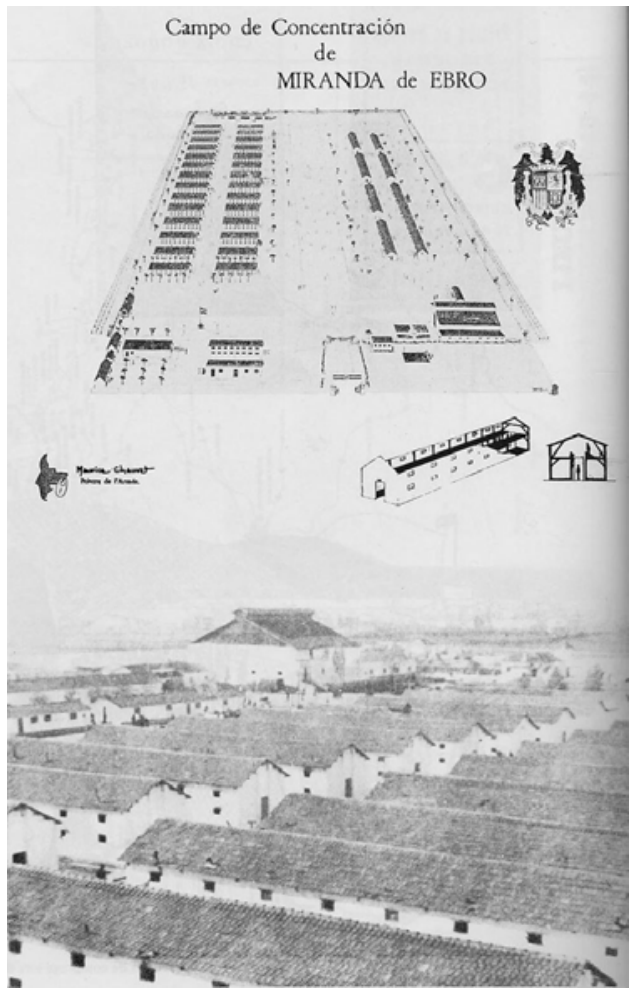

Plan and panoramic view of the Concentration Camp.

Resource: Archivo General Militar de Guadalajara. 


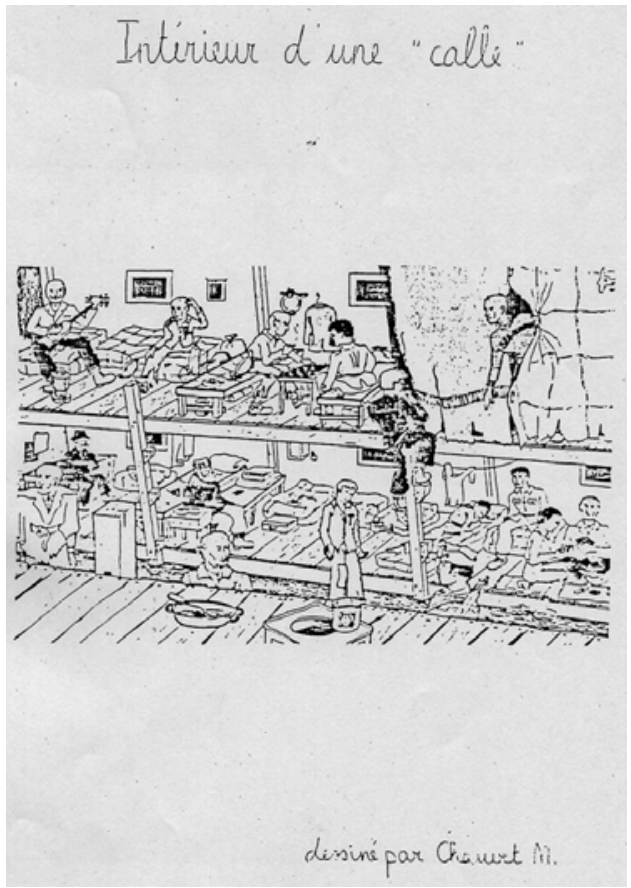

Drawing made by a prisoner inside a barrack hut.

Source: Archivo General Militar de Guadalajara. 